\title{
Дистанційне навчання у вищій медичній школі: за і проти
}

Мета роботи: визначити пріоритетні напрямки розвитку дистанційного навчання та його негативні моменти в системі вищої медичної освіти.

Всьому, що необхідно знати, навчити не можна, вчитель може зробити тільки одне - вказати дорогу.

Річард Олдінгтон

Непрогнозована ситуація щодо пандемії COVID-19 із вимушеними карантинними заходами стала перевіркою готовності не тільки для світової охорони здоров'я, а й для системи медичної освіти та внесла певні корективи в навчальний процес у вищих медичних навчальних закладах України. Освітні установи в усьому світі вимушено перейшли на електронний формат викладання i навчання, в найкоротші терміни перебудували налагоджений роками навчальний процес [5].

На сучасному етапі онлайн-навчання $є$ глобальним трендом в освіті. Воно стало невід'ємною частиною і сучасного життя, і освіти. У медичних університетах вже давно запроваджено елементи електронного навчання, одним із яких є загальновідома освітня платформа Moodle, орієнтована насамперед на організацію взаємодії між викладачем і студентами. Ця система дала можливість ефективно контролювати роботу й успішність студентів, проводити щоденний моніторинг процесу навчання і його своєчасне коректування. У дистанційному освітньому процесі застосовують такі форми навчальної діяльності, як дискусії, аудіо- і відеоконференції в ZOOM i Microsoft Teams. Викладачі активно використовують ці онлайн-платформи для читання лекцій, практичних занять, проведення консультацій [7].

Зрозуміло, що в цих умовах єдиною альтернативою для виконання навчальної програми є перехід на дистанційну освіту. Це створило форсмажорні обставини, які змусили вирішувати питання педагогічного дизайну, адаптувати під цю форму навчальні програми i, відповідно, дистанційні технології. Відбувся своєрідний ривок у масовому та екстреному впровадженні дистанційних освітніх технологій.

Питання про застосування дистанційної форми навчання в медичних навчальних закладах є диску- сійним. Перевагами дистанційної освіти є можливість навчання відразу великої кількості студентів, полегшення навчального процесу в разі навчання студентів з інвалідністю, технологічність - навчання з використанням сучасних програмних і технічних засобів. Як правило, дистанційне навчання значно дешевше, ніж традиційне, за рахунок зниження витрат на переїзди, проживання та організацію власне навчального процесу [3].

Опоненти дистанційної освіти в медицині вважають, що засвоїти практичні навички, які є головною складовою при навчанні майбутніх лікарів, таким чином неможливо. Природно, навчання лікаря практичним навичкам вимагає традиційного очного контакту $[4,6]$.

Хочу передати вам своє занепокоєння. Ті хвалебні пісні віртуального навчання та дистанційної освіти, які звучать в останні тижні, викликають в мене відчуття жаху. Мені здається, дистанційна освіта - це троянський кінь, який, користуючись пандемією, хоче прорватися через останні бастіони нашого приватного життя і освіти. Звичайно, мова не йде про надзвичайні ситуації. Зараз доводиться пристосовуватися до віртуального навчання, щоб врятувати навчальний рік.

\section{Нуччо Ордіне \\ італійськийський філософ, письменник}

Тож тепер разом поміркуємо про позитивні і негативні сторони дистанційного навчання в медичному вузі. Під час дистанційного навчання впродовж останніх місяців виявлено ряд характерних позитивних сторін:

- гнучкість навчання - студенти в зручному для себе режимі і темпі можуть освоїти електронні навчальні матеріали; 
- висока мотивація і дисциплінованість студентів;

- нова роль викладача - він є координатором навчального процесу, проводить консультування зі складних питань програми, керує навчальними проектами.

Методами асинхронної взаємодії виступають електронна пошта або електронні комп’ютерні мережі. Для індивідуалізованого контролю якості навчання при дистанційній освіті використовують тести і ситуаційні завдання, які дають можливість максимально об'єктивно оцінити кожного студента.

Вища медична школа - це нова високотехнологічна система навчального процесу, нові навчальні програми, електронні засоби навчання, нові умови для реалізації державних освітніх стандартів. Вища медична школа повинна забезпечити випускникам комплекс інтегрованих теоретичних і клінічних знань, умінь і навичок, допомогти освоїти високі світові медичні технології, сформувати здатність до соціальної адаптації фахівця. Реалізація цих завдань сприяє якісній підготовці лікаря, що спирається на міцну мотиваційну установку, глибоку спеціалізацію, актуалізацію інтелектуальних і особистісних можливостей студентів [1].

Викладачі вищої медичної школи - особлива категорія педагогів, які мають специфічні функції, умови і методи роботи, кваліфікаційні та особистісні характеристики. Займаючи викладацьку посаду, лікар повною мірою реалізує себе як педагог-професіонал. У роботі викладач орієнтується на те, що сьогодні медичні вузи готують лікарів для роботи в умовах зміни системи фінансування охорони здоров’я, вдосконалення її структури і завдань. Відповідно, підвищується відповідальність викладачів медичного вузу за результати своєї праці. Лише компетентнісний підхід у медичній освіті може забезпечити успішну адаптацію майбутнього лікаря в сучасному світі, на ринку праці, в соціальному середовищі. Природа компетентності така, що вона, як продукт навчання $є$ наслідком саморозвитку індивіда, його особистісного зростання, наслідком самоорганізації та узагальнення дієвого і особистісного досвіду. Компетентність - це спосіб існування знань, умінь, освіченості, що сприяє особистісній самореалізації, визначенню студентом свого місця в суспільстві, внаслідок чого освіта стає високомотивованою і в повному розумінні забезпечує максимальну його затребуваність [2, 3].

Чи може здійснюватись якісне дистанційне навчання на післядипломному рівні, зокрема хірургії? В цьому плані слід зазначити, що дистан- ційне навчання вимагає значних затрат кваліфікованої праці для розробки та впровадження програм, які б гарантували високу якість навчання. I дуже важливо забезпечити контроль при набутті клінічного досвіду. В умовах, що склалися, дистанційне навчання на післядипломному етапі може бути як синхронізованим, так і асинхронним. При асинхронному навчанні інтерн або курсант сам визначає темп освоєння необхідної інформації, має вибір між різними джерелами інформації, може виконувати завдання відповідно до аудиторних програм або планів, а потім передавати виконані завдання куратору групи для відповідної оцінки. Синхронна форма дистанційної освіти на сучасному рівні технологій, на нашу думку, більш приваблива. В її основі лежить спілкування із слухачем у реальному часі, через віртуальні аудиторії, використовуючи поєднання різних технічних засобів і методів передачі інформації для взаємодії із викладачем та між собою.

Чи можливо забезпечити розвиток та становлення клінічних умінь без інтегрованого навчання “обличчя до обличчя “, “із рук у руки”. Адже при вивчені будь-якої медичної спеціальності, в тому числі хірургії, ключову роль відіграє візуалізація. Незважаючи на суттєві обмеження в очній формі навчання в умовах карантину, для студентів медичних вузів, інтернів-хірургів суттєво не змінилися програма очного навчання, його форма та наповнення. Вони можуть опановувати практичні знання та вміння за більш значний період на потужних хірургічних базах, де є сучасне медичне обладнання та виконується широкий спектр хірургічних втручань. У цьому випадку велика роль відводиться куратору інтерна, який безпосередньо відповідає за його практичне та теоретичне навчання та контролює його якість. Доповненням до практичного навчання інтернів може бути використання ресурсів лабораторії інноваційних технологій освіти, що існує в провідних вищих навчальних закладах Європи та США. Основа цієї лабораторії - віртуальні тренажерні системи, що дають можливість подавати практичні навички в умовах, наближених до реальних. Ці інноваційні технології дають можливість не тільки здійснити навчання на високому сучасному рівні, а й отримати об’єктивну оцінку набутих навичок та теоретичних знань відповідно до вимог навчального процесу.

Штучний інтелект, технології, доповнені augmented reality (AR) та віртуальної реальності (virtual reality, VR), здійснили революційний прорив у дистанційній освіті. Інтерактивні моделі, peконструкції органів, відтворення на екрані інформації у 3D-проекції, тренажери-симулятори на базі 
технологій VR вже сьогодні можна використовувати для навчання та проектування хірургічного втручання. Завдяки VR інтерни в умовах реального часу можуть слідкувати за операцією або хірургічною маніпуляцією від оперуючого хірурга, переключатися на панорамний огляд місця операції та обговорювати хід операції у чаті. В цьому плані перспективним для навчання інтернів та курсантів $€$ впровадження хірургічних окулярів Google glass. Останні дають можливість слідкувати за ходом операції необмеженій кількості студентів, інтернів та курсантів, і відображати в периферійному вікні питання, на які хірург може відповідати усно. Новим у дистанційному навчанні інтернів та курсантів може бути використання платформи Fundamental, на базі якої розроблені технології FeelReal VR, що дають можливість відтворити в записі хід операцій в симуляції VR, в якій хірурги можуть практикувати і відпрацьовувати хірургічні прийоми, відчуваючи руками текстуру тканин. Все це потребує великих затрат і часу [8].

Що ж проти?

Вихваляння віртуального навчання та дистанційної освіти викликає і певне занепокоєння. Як стверджує професор університету Калабрії Нуччо Ордіне: "Мені здається, дистанційна освіта - це троянський кінь, який, користуючись пандемією, хоче прорватися через останні бастіони нашого приватного життя і освіти”. Хоча в умовах пандемії це єдиний вихід, який допоможе врятувати навчальний рік. Викликає занепокоєння впевненість багатьох науковців, які вважають, що пандемія COVID-19 - це можливість зробити такий довгоочікуваний стрибок уперед, до дистанційної освіти. Вони впевнено стверджують, що ми вже не зможемо повернутися до традиційного очного навчання, а найбільше, на що можна сподіватися - це гібридне викладання: частина занять буде очна, інша - дистанційна. Система дистанційного навчання в певних аспектах підходить лише дисциплінованим і дуже мотивованим студентам, яких не так багато. Використання сучасних телекомунікаційних програм не завжди дає можливвість проконтролювати присутність студента на занятті чи лекції. Викладачі, які втомлені приходять додому з роботи, теж найменше думають про підготовку до лекцій і занять, а ще повинні відповісти на масу запитань від студентів, які надходять на електронну скриньку. Де знайти час, щоб дати на них відповіді, і якою буде якість цих відповідей опівночі. Такі предмети, як фізика, хімія, біологія, математика, фармакологія, гістологія, патологічна анатомія, можна вивчати дистанційно. Однак складно уявити, як дистанційно вивчати хірургію, терапію, акушерство та гінекологію.

Можливість спілкування із студентами в аудиторії - це єдине, що дає справжній сенс навчання. Студенти хочуть бачити своїх викладачів у реальному житті, а не через холодний екран комп'ютера. Як правило, вони прагнуть бути подібними на них. Візуальне сприйняття викладача в аудиторії, його вміння подати матеріал, міміка, мова жестів, спілкування з пацієнтом - ось що робить навчання справжнім, живим, цікавим. Ніколи дистанційне навчання і ніяка цифрова платформа не зможуть змінити життя студента. Це може зробити лише хороший викладач! При дистанційному навчанні втрачається головна ідея університету як спільноти, що формує майбутніх лікарів, які зможуть працювати з твердими етичними переконаннями і глибоким почуттям людської солідарності і загального блага. Ми забуваємо, що без суспільного життя, без ритуалів, за якими проходять зустрічі студентів і викладачів в аудиторіях, не може бути ні справжньої передачі знань, ні виховання.

А як навчити майбутнього хірурга працювати руками? Де, коли і як він повинен засвоїти хірургічну техніку? Ні один тренажер не замінить роботу в операційній. На жаль, сьогодні ми лікарів не вчимо, головний принцип вищої школи - студент навчається біля ліжка хворого - порушений. Найімовірніше, медичним вузам доведеться надолужувати згаяне, коли епідемія піде на спад.

У перші дні дистанційного навчання освітні портали очікувано зіткнулися з технічними проблемами через великий наплив користувачів, відсутність персональних комп'ютерів і не завжди достатній рівень комп’ютерної грамотності як викладачів, так і студентів, неконтрольований режим роботи (24 год на добу 7 днів на тиждень), великий обсяг навчального матеріалу, що збільшило навантаження на викладачів у рази.

У навчанні професії лікаря дистанційні форми навчання не можуть у повному обсязі замінити клінічне навчання, оскільки не всі можливості навчання можна замінити комп'ютерним моделюванням. Тому постає питання раціонального поєднання традиційної і дистанційної форм навчання. Необхідно зазначити, що можливості дистанційних освітніх технологій при реалізації педагогічного процесу в медичному вузі досить широкі і як потенційно, так і практично можуть постійно розширюватися, але необхідне розуміння чіткої межі можливостей такого навчання для медичної освіти. 


\section{СПИСОК ЛІТЕРАТУРИ}

1. Дебердеев И. Р. Роль клинического мышления в профессиональной деятельности врача / И. Р. Дебердеев // Бюллетень медицинских Интернетконференций. - 2015. - Т. 4, Вып. 11. - С. 1174-1179.

2. Калиева Ш. С. Возможности и ограничения дистанционного обучения в преподавании медицинских дисциплиню. НАО “Медицинский Университет Караганды” / Ш. С. Калиева, Л. И. Пивень // Сборник тезисов международной онлайн-конференции “Современные вызовы медицинского образования в условиях пандемии: опыт быстрых решений и стратегические инициативы” (Караганда, 5 июня 2020 г.). Караганда, 2020. - С. 37-39.

3. Марухно В. М. Дистанционное образование в медицине / В. М. Марухно // Международный журнал экспериментального образования. - 2012. - № 4 (часть 2) - С. 154-156.

4. Юлдашова Р. У. Отношение студентов и преподавателей

\section{REFERENCES}

1. Deberdeyev, I.R. (2015). Rol klinicheskogo myshleniya v professionalnoy deyatelnosti vracha [The role of clinical thinking in the professional activity of a doctor]. Byulleten meditsinskikh Internetkonferentsiy - Bulletin of Medical Internet Conferences, 4 (11), 1174-1179 [in Russian].

2. Kaliyeva, Sh.S., \& Piven, L.I. (2020). Vozmozhnosti i ogranicheniya distantsionnogo obucheniya $\mathrm{v}$ prepodavanii meditsinskikh distsiplin [Possibilities and limitations of distance learning in teaching medical discipline]. NAO "Meditsinskiy Universitet Karagandy". Mezhdunarodnaya onlayn-konferentsiya " "Sovremennyye vyzovy meditsinskogo obrazovaniya $v$ usloviyakh pandemii: opyt bystrykh resheniy i strategicheskiye initsiativy”, Sbornik tezisov [in Russian]. 3. Marukhno, V.M. (2012). Distantsionnoye obrazovaniye v meditsine [Distance education in medicine]. Mezhdunarodnyy zhurnal eksperimentalnogo obrazovaniya - International Journal of Experimental Education, 4, 154-156 [in Russian].

4. Yuldashova, R.U., \& Navruzova, L.Kh. (2015). Otnosheniye studentov i prepodavateley k elektronnomu obucheniyu [Attitude of students and teachers to e-learning]. Pedagogicheskiy profes-

sionalizm v obrazovanii. Novosibirsk - Pedagogical Professionalism in Education. Novosibirsk, 219-220 [in Russian].

5. Bolatov, A.K., Seisembekov, T.X., Askarova, A.Zh., Baikanova, R.K., Smailova, D.S., Fabbro, E. (2020). Online-Learning due to COVID-19 improved mental health among medical students. Med. Sci. Educ., 18, 1-10.

6. Soltany, A., Hamouda, M., Ghzawi, A., Sharaqi, A., Negida, A., Soliman, S., Benmelouka, A.Y. (2020). A scoping review of the impact of COVID-19 pandemic on surgical practice. Ann. Med. Surg. (Lond.), 57, 24-36.

7. Al-Balas, M., Al-Balas, H.I. Hatim, Jaber, M., Obeidat, K., AlBalas, H., Aborajooh, E.A., Al-Taher, R., \& Al-Balas, B. (2020). Distance learning in clinical medical education amid COVID-19 pandemic in Jordan: current situation, challenges, and perspectives BMC Med. Educ., 20, 341.

8. Achi, N.E., Honein-Abouhaidar, G., Rizk, A., Kobeissi, E., Papamichail, A., Meagher, K., Ekzayez, A., Abu-Sittah, G.S., Patel, P. (2020). Assessing the capacity for conflict and health research in Lebanon: a qualitative study. Confl. Health, 14, 59.

Отримано 03.09.2020

Електронна адреса для листування: vladymyrpiatnochka@gmail.com

I. YA. DZIUBANOVSKYI, V. B. GOSHCHYNSKY, V. I. PIATNOCHKA

I. Horbachevsky Ternopil National Medical University

\section{DISTANCE LEARNING IN MEDICAL SCHOOL: PRO AND CON}

The aim of the work: to determine the priority directions for the development of distance learning, and its negative aspects in the system of higher medical education.

\section{І. Я. ДЗЮБАНОВСЬКИЙ, В. Б. ГОЩИНСЬКИЙ, В. І. ПЯТНОЧКА}

Тернопольский национальный медицинский университет имени И. Я. Горбачевского МОз Украины

\section{ДИСТАНЦИОННОЕ ОБУЧЕНИЕ В ВЫСІІЕЙ МЕДИЦИНСКОЙ ІІКОЛЕ: ЗА И ПРОТИВ}

Цель работы: определить приоритетные направления развития дистанционного обучения и его негативные моменты в системе высшего медицинского образования. 